DOI: 10.2478/ausae-2021-0007

\title{
Preliminary study on species variability and evolutionary status of African walnut (Plukenetia conophora)
}

\author{
Nwakuche Chinenye ONWUBIKO,,$^{*}$ Queen Ifeoma EMEREOLA, ${ }^{1}$ \\ Chinyere Prisca ANYANWU, ${ }^{1}$ Grace Ovute CHIMDI $^{2}$ \\ ${ }^{1}$ Department of Crop Science and Technology, Federal University of Technology, \\ Owerri 1526, Nigeria. \\ 2 Department of Agricultural Technology, Federal Polytechnic Bauchi, \\ Bauchi 0231, Nigeria \\ *E-mail: nwakuche.onwubiko@futo.edu.ng
}

Manuscript received 13 July 2021; revised 22 August 2021; accepted 30 August 2021

\begin{abstract}
An analysis of the biochemical composition of African walnut seeds collected from two different geographical areas, Nigeria and Cameroon, was used to conduct the primary assessment of varietal differences and evolutionary status of Plukenetia conophora. The experiment was conducted at the Laboratory of Department of Biochemistry and Technology, Federal University of Technology, Owerri, Nigeria. The experimental design was completely randomized design with five replications. Significant difference $(\mathrm{P}>0.05)$ was not observed with the proximate properties of the seeds of the two lines except for carbohydrate. However, higher values in protein $(28.32 \%)$, crude fat $(5.67 \%)$, ash (4.33\%), and moisture $(38.44 \%)$ content were obtained for the line from Nigeria, while the line from Cameroon had higher values for carbohydrate $(20.87 \%)$ and crude fibre $(9.32 \%)$. With regard to mineral composition, significant difference $(\mathrm{P}<0.05)$ was observed in some mineral elements such as manganese, sodium, and chromium. Anti-nutritional composition such as proximate properties did not show any significant difference between the two lines. However, the line from Nigeria had higher values of phytate $(6.27 \%)$ and oxalate $(0.11 \%)$, while a higher content of tannin $(0.36 \%)$ and saponin $(0.27 \%)$ was obtained for the line from Cameroon. Evidently, the result obtained was not substantial to establish varietal differences between the two lines; nevertheless, it showed some level of evolutionary changes in the crop over the years.
\end{abstract}

Keywords: African walnut, biochemical properties, variability, evolution 


\section{Introduction}

Modern cultivated crops were developed from wild species. Over the years, certain changes occurred in wild species to convert them into modern cultivated crops. The development of both heritable and non-heritable features enabled the modernization of wild species. These features helped plants to adapt to and survive changes in different environments. Invariably, adaptable features of plants change periodically to reflect the current conditions of the environment they exist in. The development of adaptable features for different environments is one of the major factors that create differences in plants. This has led to species diversity and the evolution of plant varieties. Among other factors, mutation, hybridization, polyploidy, and selection are processes that can create differences in plants, and they can occur both naturally and artificially. The impact of these processes on the development of plant varieties has been reported [1, 2, 3], necessitating the periodical assessment of crops (especially semi-wild and wild economic plants) to determine the possible differences that may have occurred between and within species over the years. The establishment of varietal differences in crop species is very important in crop improvement programmes. This is very useful in germplasm management: in determining the best conservation and utilization methods of germplasm. Further, the assessment of varietal differences within species can be useful in determining the evolutionary status of crop species, especially among relatives of closely related species. In recent times, the assessment of intra- and interspecific variations between and within species have been successfully carried out through studies on nutritional composition of crops [4,5]. The similarities and differences established in studies can be utilized in the botanical classification of crops. This can also help in determining the relatives of crop species, thereby facilitating simple classification.

African walnut (Plukenetia conophora) is a shrub crop that is commonly found growing in semi-wild areas in the forest zones of Africa and India. This climbing shrub that grows between 10 and $20 \mathrm{ft}$ long is popular and cherished for its nutritious edible nuts that are cooked and consumed as snacks [6, 7, 8]. African walnut has outstanding medicinal, nutritive, traditional, economic, and industrial qualities. Several studies have been carried out on the assessment of proximate, mineral, and phytochemical composition of African walnut [9, 10, 11, 12, 13], but none so far have reported the comparative evaluation of biochemical constituents of seeds of this crop collected from different agro-geographical areas. Hence, in this study, biochemical markers were used to assess the varietal differences in African walnut from two different locations. The established variation between the lines was used to investigate the evolutionary status of this crop, based on the report that mutation can alter the chemical content of plants [1]. 


\section{Materials and methods}

The materials comprised seeds of African walnut obtained from two different geographical areas, Nigeria and Cameroon.

\section{Methods}

\section{Sample collection}

Seeds of the Plukenetia conophora crop grown in Nigeria and Cameroon were used for the study. The source of the seeds was the germplasm collection of the Department of Crop Science and Technology, Federal University of Technology Owerri.

\section{Sample preparation}

These seeds of African walnut were first sorted and cleaned before being soaked in water for 20 hours, after which they were dehulled and dried. The testa was subjected to grinding in a mortar. The dehulled seeds were also subjected to grinding in a mortar. Both the ground testa and the ground cotyledons were used for analysis.

\section{Proximate analysis}

This was carried out to determine the macronutrient in seed samples. The purpose was to evaluate the crude protein, moisture content, fat content, crude fibre, ash, and carbohydrate content in the seeds.

\section{Crude protein}

To determine the crude protein content of the Walnut seeds, the micro-Kjeldahl method, as stated in standard procedure (A.O.A.C. 2000), was used. This analysis was carried out in duplicate.

Crude fibre

The standard procedure (A.O.A.C. 2000) was used to establish the crude fibre content of the samples. It was carried out in duplicate and calculated as follows:

$$
\text { Crude fibre }(\%)=\frac{F 1-F 2}{W} \times 100 \text {, }
$$

where $\mathrm{F}_{1}=$ weight before ignition,

$\mathrm{F}_{2}=$ weight after ignition, $\mathrm{w}=$ weight of the sample before the analysis. 
Crude fat

Crude fat was determined by soxhlet extraction according to the standard procedure (A.O.A.C. 2000). It was also carried out in duplicate and calculated as follows:

$$
\text { Fat }(\%)=\frac{s b-s a}{W} \times 100,
$$

where $S_{a}=$ weight of flask before extraction,

$\mathrm{S}_{\mathrm{b}}=$ weight of the flask + oil after extraction,

$\mathrm{W}=$ weight of the sample,

\section{Moisture content}

The moisture content of the walnut seeds was determined following the standard procedure (A.O.A.C. 2000). It was carried out in duplicate and calculated as follows:

$$
\text { Moisture content }(\%)=\frac{M s-M t}{W} \times 100 \text {, }
$$

where $\mathrm{M}_{\mathrm{s}}$ = weight of the moisture can + sample before drying,

$\mathrm{M}_{\mathrm{t}}=$ weight of the moisture can + sample after drying,

$\mathrm{W}=$ weight of the sample used.

\section{Carbohydrate}

The method used to determine the carbohydrate content was the nitrogen-free method by A.O.A.C. (2000). It was obtained by the calculation of weight difference between $100 \%$ and the summation of other proximate parameters such as extracts free of nitrogen or nitrogen-free extract (NFE).

$\%$ Carbohydrate $(\mathrm{NFE})=100 \%-(\mathrm{Mo}+\mathrm{Pr}+\mathrm{F} 1+\mathrm{As}+\mathrm{F} 2)$

Mo $=$ moisture, $\mathrm{Pr}=$ protein, $\mathrm{F} 1=$ fat, $\mathrm{As}=\mathrm{Ash}$, and $\mathrm{F} 2=$ crude fibre.

Ash

The ash content of African walnut seed was obtained following the standard procedure (A.O.A.C. 2000). It was carried out in duplicate and calculated as follows:

Ash contents $(\%)=\frac{A 2-A 1}{W} \times 100$,

where $A_{2}=$ weight of crucible + sample before the addition of ash,

$\mathrm{A}_{1}$ = weight of crucible + sample after the addition of ash, $\mathrm{W}=$ weight of the sample used. 


\section{Anti-nutritional (phytochemical) analysis}

This was carried out to extract, screen, and identify the medicinally active substances found in seeds of African walnut.

\section{Oxalate}

To determine the oxalate content, two grams ( $2 \mathrm{~g}$ ) of each of the walnut samples were placed in a $250 \mathrm{ml}$ volumetric flask that was suspended in $190 \mathrm{ml}$ of distilled water. To each sample, $10 \mathrm{ml}$ of $6 \mathrm{~N}$ HCL solution was added, then cooled, and it was filled with distilled water up to the $250 \mathrm{ml}$ mark of the flask. The samples were filtered, and the duplicate portion of $125 \mathrm{ml}$ of the filtrate was measured into the beaker. This was followed by the addition of four drops of methyl red indicator, after which cone ammonia solution drop-wise were added until the solution changed from pink to yellow. The solution was then heated to $90{ }^{\circ} \mathrm{C}$, cooled and filtered to the precipitate containing ferrous ion. Again, the filtrate was heated to $90{ }^{\circ} \mathrm{C}$, and $10 \mathrm{ml}$ of $\mathrm{CaCl}_{2}$ solution was added while the sample was consistently being stirred. Then, the filtrate was dissolved in $10 \mathrm{ml}$ of $20 \% \mathrm{H}_{2} \mathrm{SO}_{4}$, which was diluted to $200 \mathrm{ml}$ with distilled water. Aliquots of $125 \mathrm{ml}$ of the filtrate were heated to near boiling and filtrated against $0.05 \mathrm{M} \mathrm{KMnO}_{4}$ solution to obtain a pink colour, which persisted for $30 \mathrm{sec}$. Determination of the oxalate contents of each sample was achieved by calculation.

\section{Phytate}

Two grams of each sample were weighed into a conical flask of $250 \mathrm{ml}$. The samples were soaked for $3 \mathrm{hrs}$ in a conical flask with $100 \mathrm{ml}$ of $2 \% \mathrm{Hcl}$, after which they were filtered with white man filter paper (No. 1). Fifty ml of each filtered sample was placed in a $250 \mathrm{ml}$ beaker. Then, $10 \mathrm{ml}$ of $0.3 \%$ ammonium thiocyanate solution was added to each sample's solution as colour that persisted for $5 \mathrm{~min}$. The phytate was calculated from the titre value.

\section{Saponin}

In a water bath, the suspension was heated for about 4 hours at about $55{ }^{\circ} \mathrm{C}$ while being stirred continuously. With $200 \mathrm{ml}$ of $20 \%$ ethanol, the residue was reextracted after filtering the mixture. At about $90{ }^{\circ} \mathrm{C}$ in a water bath, the extracts that were combined were reduced to $40 \mathrm{ml}$. Twenty $\mathrm{ml}$ of diethyl ether was added to the concentrate and shaken vigorously after transferring it into a $250 \mathrm{ml}$ separating funnel. The purification process was carried out twice by discarding the ethanol layer while the aqueous layer was being recovered. This was followed by the addition of $60 \mathrm{ml}$ of n-butanol. With $10 \mathrm{ml}$ of $5 \%$ aqueous sodium chloride, the combined n-butanol extracts were washed twice. The resultant solution was heated 
in a water bath for evaporation, and the sample was dried in an oven to get a constant weight. Using difference in weight, the saponin content was calculated.

\section{Tannin}

This was carried out by weighing out 500 milligrams of each sample into a 100 $\mathrm{ml}$ plastic bottle. To each sample, $50 \mathrm{ml}$ of distilled water was added, and it was shaken for 1 hour with the help of a mechanical shaker. The resultant solution was filtered into a $50 \mathrm{ml}$ volumetric flask and filled up to mark. This was followed by pipetting out $5 \mathrm{ml}$ of the filtrate into a tube, then mixed with $3 \mathrm{ml}$ of $0.1 \mathrm{M}$ $\mathrm{FeCl}_{3}$ in $0.1 \mathrm{~N} \mathrm{HCl}$, whereafter $0.008 \mathrm{M}$ potassium ferricyanide was added. With a spectrophotometer at $120 \mathrm{~nm}$ wavelength, the absorbance rate was measured within 10 minutes. A blank sample was prepared, the colour also developed and was read at the same wavelength. A standard was prepared using tannin acid to get $100 \mathrm{ppm}$ and measured.

\section{Mineral composition analysis}

The amount of $\mathrm{K}, \mathrm{Na}$, and $\mathrm{Ca}$ in African walnut seeds were determined by flame photometry according to the standard procedure. Iron content was determined by DREL/5 spectrophotometer in line with the standard procedure; likewise, magnesium content was determined by the EDTA method in accordance with the standard procedure. The colorimetric method was used to determine the Manganese, while Zinc was determined by the Zincon method - by the adoption of the standard methods for the examination of water and wastewater at a wavelength of $575 \mathrm{~nm}$. To obtain the copper content, the standard procedure was applied (A.O.A.C. 2000).

\section{Results}

The results of the proximate composition of the two lines of African walnut are presented in Table 2. It showed no significant difference $(\mathrm{P}>0.01)$ for any of the two lines except for carbohydrate. However, the moisture content of the line sourced from Nigeria (38.44\%) was higher than that from Cameroon (36.21\%); equally, the crude protein $(28.32 \%)$ and ash $(4.33 \%)$ content of the line from Nigeria was higher than that of the line from Cameroon (crude protein: $0.11 \%$, ash: $3.63 \%$ ). Contrarily, the crude fibre $(9.32 \%)$ and crude fat (4.73\%) content of the line from Cameroon was higher than that from Nigeria (crude fibre: $8.78 \%$, crude fat: $4.73 \%$ ).

The mineral composition results of the lines (Table 3) showed that some mineral elements, such as magnesium, sodium, and chromium, had significant differences $(\mathrm{P}<0.01)$ between the two lines. Contrarily, other mineral elements, such as calcium, iron, potassium, manganese, and copper, did not show any significant 
difference. This result further showed that the line from Nigeria had higher content of calcium $(26.07 \mathrm{mg} / \mathrm{l})$, potassium $(120.00 \mathrm{mg} / \mathrm{l})$, zinc $(0.83 \mathrm{mg} / \mathrm{l})$, and copper $(1.01 \mathrm{mg} / \mathrm{l})$ than the line from Cameroon (calcium: $8.87 \mathrm{mg} / \mathrm{l}$, potassium: 100.00, zinc: $0.558 \mathrm{mg} / \mathrm{l}$, copper: $1.013 \mathrm{mg} / \mathrm{l})$. On the other hand, the iron $(0.0140 \mathrm{mg} / \mathrm{l})$ and copper (1.76) content of the line from Cameroon was higher than that from Nigeria (iron: 0.120mg/l, copper: 1.01).

The ANOVA results of the anti-nutritive (phytochemical) composition of the seeds of two lines (from Nigeria and Cameroon) of African walnut did not show any significant difference $(\mathrm{P}>0.01)$ (Table 1$)$. However, the phytate $(0.27 \%)$ and oxalate $(0.11 \%)$ content of the line from Cameroon was higher than that from Nigeria (phytate: $0.06 \%$, oxalate: $0.03 \%$ ). On the other hand, the tannin content of the line from Nigeria $(0.36 \%)$ was higher than that from Cameroon $(0.31 \%)$; likewise, the saponin content of the line from Nigeria $(0.27 \%)$ was also higher than that from Cameroon $(0.235 \%)$.

Table 1. Results of the anti-nutritional composition of the two African walnut lines

\begin{tabular}{lcccc}
\hline Treatments & Phytate \% & Oxalate $\%$ & Tannin $\%$ & Saponin $\%$ \\
\hline Nigeria & 0.066 & 0.034 & 0.361 & 0.275 \\
\hline Cameroon & 0.270 & 0.113 & 0.314 & 0.235 \\
\hline LSD $(0.05)$ & $\mathrm{ns}$ & $\mathrm{ns}$ & $\mathrm{ns}$ & $\mathrm{ns}$ \\
\hline
\end{tabular}

Table 2. Results of the proximate analysis of the two African walnut lines

\begin{tabular}{lcccccc}
\hline Treatments & Protein \% & $\begin{array}{c}\text { Crude fibre } \\
\%\end{array}$ & Fat \% & Ash \% & Moisture \% & $\begin{array}{c}\text { Carbo- } \\
\text { hydrate \% }\end{array}$ \\
\hline Nigeria & 28.38 & 8.78 & 5.67 & 4.33 & 38.44 & 14.46 \\
\hline Cameroon & 25.33 & 9.32 & 4.73 & 3.63 & 36.24 & 20.87 \\
\hline LSD (0.05) & $\mathrm{ns}$ & $\mathrm{ns}$ & $\mathrm{ns}$ & $\mathrm{ns}$ & $\mathrm{ns}$ & $\mathrm{ns}$ \\
\hline
\end{tabular}

Table 3. Results of the mineral composition of the two African walnut lines

\begin{tabular}{|c|c|c|c|c|c|c|c|c|c|c|}
\hline 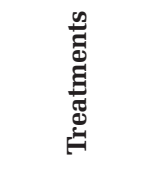 & 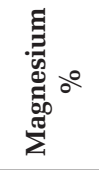 & 劳 & 。ํํ & 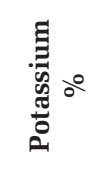 & 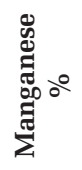 & 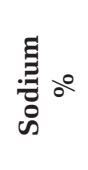 & 苛。 & 泀。 & 运 $0^{\circ}$ & 。․루 \\
\hline Nigeria & $2.27 \%$ & 26.07 & 0.12 & 120.00 & 3.70 & 2.43 & 1.013 & 0.71 & 0.83 & 0.01 \\
\hline Cameroon & $8.87 \%$ & 25.23 & 0.14 & 100.00 & 1.30 & 0.40 & 1.765 & 1.76 & 0.55 & 0.15 \\
\hline LSD (0.05) & 2.44 & ns & ns & ns & ns & 2.007 & ns & 0.43 & & \\
\hline
\end{tabular}

Note: $\mathrm{ns}=$ not significant. 


\section{Discussion}

Fruits and nuts play a very important role in the nutrition and diet of rural dwellers. They are the major source of vitamins and minerals for most people living in rural areas. These fruits and nuts are usually obtained from wild and semi-wild plants because some people believe that they are better sources of vitamins and minerals than the genetically improved crop species. The nutritional value placed in food from these natural sources often attract people living in cities to rural areas. In this study, seeds of African walnut found in semi-wild areas of Nigeria and Cameroon were used to investigate varietal differences based on proximate, mineral, and anti-nutritional composition.

Proximate analysis results of the two lines of African walnut did not show any significant difference except for carbohydrate. This implies that the nutrient content of the line from Nigeria was the same as that from Cameroon except for their carbohydrate content. This result indicates that there is little or no difference between the two lines. The significant difference observed in carbohydrate content is not adequate for establishing varietal difference between the two lines. However, the results of this study showed that the protein, crude fibre, ash, and moisture content of the two lines varied. In addition, no single line had a higher content of these elements than the other one. This result may have some implications for the evolutionary status of this crop. Generally, it was observed in this study that the seed of African walnut is a rich source of protein, carbohydrate, and fat. Several workers reported that any food plant that can provide $12 \%$ or more of its energy from protein is considered a valuable protein source [8, 14]. Invariably, this study has shown that African walnut is an energy-rich food substance. This is in agreement with the report of other workers that this crop is an excellent source of polysaturated fatty acids, such as alpha linoleic acid, it contains Omega-3 essential fatty acids, and it also provides more Omega-3 per pound than any other food [14, $15,16]$. African walnut therefore can play a vital role in providing food security to people living in rural areas. Previous studies on the proximate analysis of African walnut seed have reported a similar result [12, 15, 16, 17, 18, 19, 20, 21].

The results of mineral composition showed significant differences $(\mathrm{P}>0.01)$ in few elements, such as magnesium, sodium, and chromium, between the two lines. The composition of other mineral elements (calcium, iron, potassium, manganese, and copper) was statistically the same for the two lines. Seemingly, it can be deduced that some level of variation exists between the two lines of African walnut based on the result of the mineral elements that showed significant differences between the two lines. However, this result is not conclusive enough to clearly establish varietal differences between the lines, but it may suggest that the evolutionary status of this crop is not static. Again, the fact that the content of the other mineral elements that did not show significant difference between 
the two lines were not the same also showed that evolutionary changes are in progress in the crop. The details of this result showed that African walnut contains essential vitamins and minerals such as magnesium, iron, calcium, copper, zinc, and manganese. Some researchers have reported a similar result on the mineral composition of African walnut [8, 14], and these mineral elements play a very important role in boosting the immune system of the body as well as in preventing anaemia [22].

Analysing the composition of the anti-nutritive content of the two African walnut lines did not show any significant difference contrarily to the results of the proximate and mineral composition, which showed varying levels of significant differences in their content. This implies that there was no variability between the lines based on their anti-nutritive composition. However, the details of this result showed that the anti-nutritive constituents of the two lines were again not the same. The line from Nigeria had a lower content of phytate and oxalate, while the tannin and saponin content of the line from Cameroon was higher. Generally, the low content of tannin (0.31\%), phytate $(0.06 \%)$, oxalate $(0.03 \%)$, and saponin $(0.27 \%)$ was observed in the two lines. A previous study examining the phytochemical composition of boiled nuts of this crop reported a similar result [21]. The low content of anti-nutrients in African walnut implies that it is good for human consumption. Udedi et al. (2014) [16] suggested serving the nut of this crop as a food supplement in school children feeding programmes.

In summary, results of this investigation have shown that neither the line from Nigeria nor the one from Cameroon had consistently higher values in proximate, mineral, and anti-nutrient composition. Therefore, the result of biochemical constituents of the investigated two lines of African walnut was not adequate for establishing varietal differences. However, the observed few significant differences in the biochemical composition (proximate and mineral elements) of the two lines suggest that the development of African walnut into diverse ecotypes is under way, although at a very slow pace. These two lines of African walnut have been in existence in these areas for many years [9, 23], and the expectation was that over the years the two lines should have significantly developed into different forms that can be established through assessing the biochemical content of their seeds. According to Singh et al. (1996) [24], the production of certain biochemical components is a reflection of genetic variation, which may account for variations observed in some morphological attributes such as leaflet size and colour. 


\section{References}

[1] Allard, R. W. (1999), Principles of plant breeding ( $2^{\text {nd }}$ edition). John Wiley and Sons, Inc.

[2] Uguru, M. I. (2005), Crop genetics and breeding (revised ed.), Nsukka: Epharate Press.

[3] Alix, K., Gerard, P. R., Schwarzacher, T., Heslop-Harrison, J. S. (2017), Polyploidy and interspecific hybridization: Partners for adaptation, speciation and evolution in plants. Annals of Botany 120, 183-194.

[4] Varga, F., Carović-Stankoab, K., Ristić, M., Grdiša, M., Liber, Z., Šatovićab, Z. (2017), Morphological and biochemical intraspecific characterization of Ocimum basilicum L. Industrial Crops and Products 109(15), 611-618.

[5] Alghamdi, S. S., Khan, M. A., Migdadi, M. H., EL-Harty, E .H., Afzal, M., Farooq, M. (2019), Biochemical and molecular characterization of cowpea using seed storage proteins and SRAP marker patterns. Saudi Journal of Biological Science 26, 74-82.

[6] Enujiugha, V. N. (2003), Chemical and functional characteristics of conophor nut. Pakistan Journal of Nutrition 2(6), 335-338.

[7] Srinivasan, A., Viraraghavan, T. (2008), Removal of oil by walnut shell media. Journal of Bioresource Technology 99, 8217-8220.

[8] Edem, C. A., Dosunmu, M. I, Bassey, F. I. (2009), Determination of proximate composition, ascorbic acid and heavy metal content of African walnut (Tetracarpidium conophorum). Pakistan Journal of Nutrition 8(3), 225-226.

[9] Ajaiyeoba, E. O., Fadare, D. A. (2006), Antimicrobial potential of extracts and fractions of the African walnut (Tetracarpidium conophorum). African Journal of Biotechnology 5(22).

[10] Isong, N., Alozie, Y. E., Ekwere, Y. (2013), Physicochemical properties of African walnut (Tetracarpidium conophorum) oil and its suitability for domestic and industrial uses Nigerian. Journal of Agriculture, Food and Environment 9(3), 12-15.

[11] Apeh, V. O., Agu, C. V., Ogugua, V. N., Uzoegwu, P. N., Anaduaka, E. G., Rex, T. E. (2014), Effect of cooking on proximate, phytochemical constituents and hematological parameters of Plukenetia conophorain male albino rats. European Journal of Medicinal Plants 4(12), 1388-1399.

[12] Akpoghelie, J. O., Esemedafe, J. U., Okoh, R., Ugochukwu, G. C. (2016), The nutritional assessment of the walnut (Plukenetia conophora) seed purchased in an open market in Warri, Delta State. Nigeria. Journal of Chemical Society of Nigeria 41(1).

[13] Igara, C. E., Omoboyowa, D. A., Uchegbu, R. I., Ahuchaogu, A. A. (2017), Phytochemical composition, proximate analysis and vitamin content of 
(Tetracarpidium conophorum) walnut $\quad[$ sic $] \quad$ seed. Chemistry Research Journal 2(5), 1-8.

[14] Kanu, A. M., Kalu, J. E., Okorie, A. C. (2015), Nutritional and health values of African walnut (Tetracarpidium conophorum). International Journal of Scientific \& Technology Research 4(9).

[15] Udedi, S. C., Ani, O. N., Anajekwu, B. N., Igwilo, I. O., Ononamadu, C. J., Adindu, C. S., Okafor, U. M. (2013), Comparative proximate analyses of raw and cooked Plukenetia conophora (African walnut) found in Akwa, Anambra State, Nigeria. The Bioscientist 1(2), 114-118.

[16] Udedi, S. C., Ani, O. N., Anajekwu, B. N., Ononamadu, C. J., Igwilo, I. O., Ibeabuchi, C. G., Ifemeje, J. C., Lukong, C. B., Ogbuozobe, G. O. (2014), Nutritional composition and antioxidant activity of African walnut, Tetracarpidium conophorum. The Journal of Applied Biochemistry. Photon 107, 170-180.

[17] Bowsher, C., Steer, A. D., Tobin, A. (2008), Plant biochemistry. New York, NY: Garland Science.

[18] Ekwe, C. C., Ihemeje, A. (2013), Evaluation of physiochemical properties and preservation of African walnut (Tetracarpidium conophorum). Academic Research International 4(6), 501-512.

[19] Arinola, S. O., Adesina, K. (2014), Effect of thermal processing on the nutritional, anti-nutritional and antioxidant properties of T. conophrum. Journal of Food Processing 1-4.

[20] Oyekale, K. O., Odutayo, O. I., Esan, E. B., Ogunwemimo, K. O., Denton, O. A., Bolaji, D. T. (2015), Comparative studies on phytochemical and proximate composition of four morphological distinct segment of the conophor seedlings (Plukenetia conophora). Brazilian Journal of Biological Sciences 3, 91-100.

[21] Chickezie, U. N. (2017), Phytochemical and proximate compositions of Plukenetia conophora (African walnut) seeds. International Journal of Research Studies in Bioscience 5(10), 25-31.

[22] Ojobor, C. C., Anosike, C. A., Ani, C. C. (2015), Studies on phytochemical and nutritional properties of Plukenetia conophora (Black walnut) seeds. Journal of Global Biosciences 4(12), 1366-1372.

[23] Dalziel, J. M. (1937), The useful plants of West Tropical Africa. London: Whitefriars Press.

[24] Singh, A. K., Subrahmanyam, P., Santosh, G. (1996), Variation in a wild groundnut species, Arachis duranensis Krapov and W. C. Gregory. Genetic Resources and Crop Evolution 43, 135-142. 